\title{
Genetic Diversity and Molecular Markers in Introduced and Thai Native Apple Snails (Pomacea and Pila)
}

\author{
Bungorn Thaewnon-ngiw, Sirawut Klinbunga ${ }^{\dagger} *$ Kantimanee Phanwichien $^{\ddagger}$ Nitsri Sangduen ${ }^{\S}$, \\ Nitaya Lauhachinda' and Piamsak Menasveta ${ }^{\dagger, \#}$ \\ Program of Bioscience, Graduate School of Kasetsart University, Bangkok 10900, Thailand \\ 'Marine Biotechnology Research Unit, National Center for Genetic Engineering and Biotechnology (BIOTEC), National Science and \\ Technology Development Agency (NSTDA), 113 Paholyothin Rd., Klong 1, Klong Luang, Pathumthani 12120, Thailand \\ "Department of Zoology, ${ }^{\S}$ Department of Genetics, \\ 'Department of General Science, Faculty of Science, Kasetsart University, Bangkok 10900, Thailand \\ "Department of Marine Science, Faculty of Science, Chulalongkorn University, Bangkok 10330, Thailand
}

Received 19 November 2003, Accepted 2 January 2004

The genetic diversity and species-diagnostic markers in the introduced apple snail, Pomacea canaliculata and in the native Thai apple snails; Pila ampullacea, $P$. angelica, $P$. pesmei, and $P$. polita, were investigated by restriction analysis of COI and are reported for the first time. Twentyone composite haplotypes showing non-overlapping distributions among species were found. Genetic heterogeneity analysis indicated significant differences between species $(\mathrm{P}<0.0001)$ and within $P$. pesmei $(\mathrm{P}<$ $0.0001)$ and $P$. angelica $(P<0.0004)$. No such heterogeneity was observed in Pomacea canaliculata $(P>0.0036$ as modified by the Bonferroni procedure), $P$. ampullacea $(\mathrm{P}=$ 0.0824-1.000) and $P$. polita $(P=1.0000)$. A neighbor-joining tree based on genetic distance between pairs of composite haplotypes differentiated all species and indicated that $\boldsymbol{P}$. angelica and $P$. pesmei are closely related phylogenetically. In addition, the 16S rDNA of these species was cloned and sequenced. A species-specific PCR for $P$. canaliculata was successfully developed with a sensitivity of detection of approximately $50 \mathrm{pg}$ of the target DNA template. The amplification of genomic DNA (50 pg and $25 \mathrm{ng}$ ) isolated from the fertilized eggs, and juveniles $(1,7$, and $15 \mathrm{~d}$ after hatching) of Pomacea canaliculata was also successful, and suggested that Pomacea canaliculata and Pila species can be discriminated from the early stages of development.

Keywords: Apple snails, Genetic diversity, PCR-RFLP, Pila, Pomacea

*To whom correspondence should be addressed.

Tel: 66-2-2185279; Fax: 66-2-2547680

E-mail: sirawut@biotec.or.th

\section{Introduction}

The apple snails indigenous to Thailand are members of the genus Pila. The group comprises $P$. ampullacea, $P$. angelica, $P$. gracilis, $P$. pesmei and $P$. polita according to Keawjam (1986). Whereas P. ampullacea, P. pesmei and P. polita are sympatrically distributed in the north, northeast, and central regions, $P$. angelica and $P$. gracilis are found only on the Thai peninsula. Of these species, only $P$. polita is easily differentiated morphologically, the other four species present taxonomic difficulties and can be misidentified (Keawjam, 1986; 1987).

The golden apple snail, Pomacea canaliculata (Lamarck, 1822) was illegally introduced into Thailand to clean fish aquaria because of its ability to consume several kinds of aquatic plants and algae, and was first discovered in the wild in 1984 (Keawjam and Upatham, 1990). Because of its short maturation time (2-3 mo) and its potential to lay large numbers of eggs (Cowie, 2002), Pomacea canaliculata continues to have an increasing impact on freshwater communities. The severe observed decrease in the Pila spp. population may be the result of competition with Pomacea canaliculata (Lauhachinda et al., 1988). Moreover, the golden apple snail has been reported to have caused serious damage to rice crops since 1996 and it is now regarded as being the most important rice pest in Thailand (Janyapeth and Archawakom, 1999).

The golden apple snails in Thailand exhibit variability in shell color and banding pattern, which ranges from golden yellow to olive yellow and dark olive green, and the snails have numbers of small and large bands. Using shell morphology, male reproductive organ anatomy and allozymes, Keawjam and Upatham (1990) classified the golden apple 
snails in Thailand into three different species; Pomacea canaliculata, Pomacea insularum, and Pomacea sp.

The taxonomy of Pila and Pomacea snails has been based principally on morphological characteristics. However, external characteristics (e.g. shell morphology) are influenced by habitat and the environment (Keawjam 1986 and 1987). Thus, the two sympatric species may be morphologically similar and misidentified as a single species. On the other hand, allopatric populations inhabiting different habitats may show ecomorphological variations and a questionable species status.

The objectives of this study were to determine the levels of genetic diversity of the introduced (Pomacea canaliculata) and the native apple snails ( $P$. ampullacea, $P$ angelica, $P$. pesmei, and $P$. polita) in Thailand, and to identify molecular genetic markers capable of facilitating the taxonomic identification of Pila snails by using restriction analysis of cytochrome oxidase subunit I (COI). A Pomacea canaliculata-specific marker was also developed from $16 \mathrm{~S}$ rDNA, to differentiate Pomacea and Pila snails at the early stages of development.

\section{Materials and Methods}

Sampling Three hundred and twenty-four apple snails; Pomacea canaliculata $(N=180), P$. ampullacea $(N=28), P$. angelica $(N=$ 27), $P$. pesmei $(N=63)$ and $P$. polita $(N=26)$ were collected from their respective ranges in Thailand (Fig. 1 and Table 1). The identification of apple snails was carried out according to Keawjam (1986) and Keawjam and Upatham (1990). Foot tissue was dissected out and kept at $-80^{\circ} \mathrm{C}$ until required.

DNA extraction The total DNA of each snail was extracted from a piece of foot tissue using a phenol-chloroform-proteinase $\mathrm{K}$ method (Winnepenninckx et al., 1993). DNA concentration was determined spectrophotometrically (Maniatis et al., 1982), and extracted DNA was stored at $4{ }^{\circ} \mathrm{C}$ until required.

PCR, restriction enzyme digestion, and agarose gel electrophoresis The mitochondrial cytochrome oxidase subunit I (COI) gene segment of each apple snail $(710 \mathrm{bp})$ was amplified using primers LCO1490: 5'-GGT CAA CAA ATC ATA AAG ATA TTG G-3' and HCO2198: 5'-TAA ACT TCA GGG TGA CCA AAA AAT CA-3' (Folmer, et al., 1994). Amplification was carried out in a $50 \mu \mathrm{l}$ reaction volume containing $10 \mathrm{mM}$ Tris- $\mathrm{HCl}, \mathrm{pH} 8.8$, $50 \mathrm{mM} \mathrm{KCl}, 0.1 \%$ Triton X-100, $100 \mathrm{mM}$ of each dNTP, $2.0 \mathrm{mM}$ $\mathrm{MgCl}_{2}, 0.5 \mu \mathrm{M}$ of each primer, 1 unit of DyNAzyme ${ }^{\mathrm{TM}}$ II DNA Polymerase (Finnzymes, Espoo, finland), and $25 \mathrm{ng}$ of DNA template.

PCR was performed in a thermocycler (OmniGene, Hybaid, Franklin, USA) and consisted of predenaturation at $94^{\circ} \mathrm{C}$ for 3 minutes followed by 10 cycles of denaturation at $94^{\circ} \mathrm{C}$ for 1 minute, annealing at $45^{\circ} \mathrm{C}$ for 1 minute and extension at $72^{\circ} \mathrm{C}$ for 1 minute, and an additional 35 cycles at higher stringency using the same conditions except an annealing temperature of $53^{\circ} \mathrm{C}$. Final extension was carried out at $72^{\circ} \mathrm{C}$ for 7 minutes.

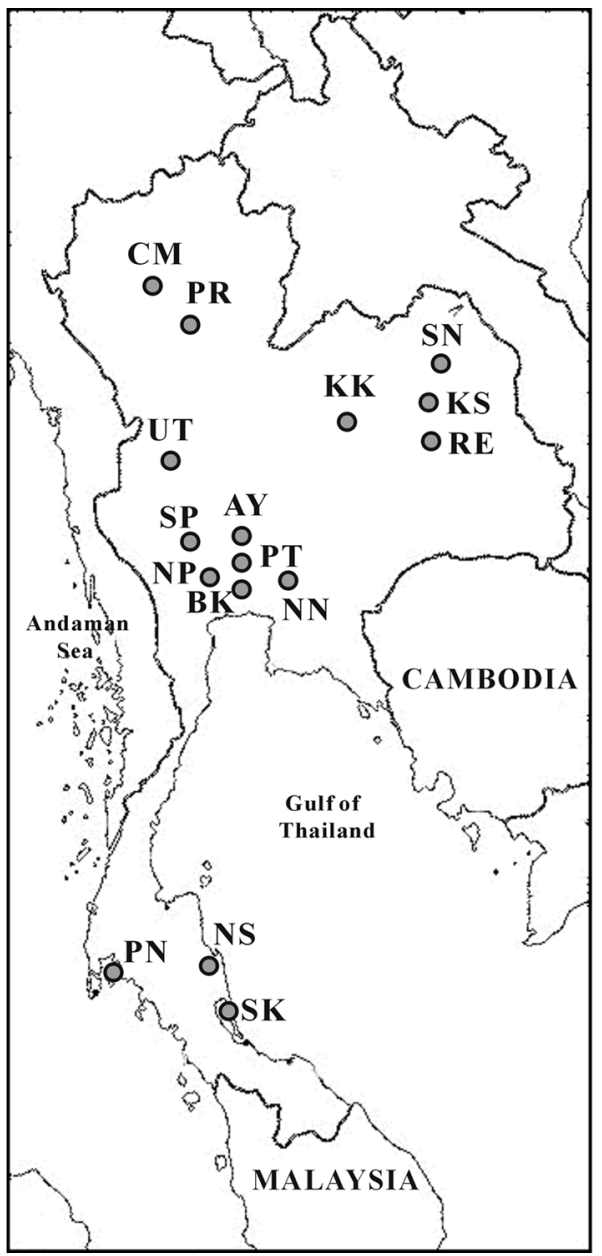

Fig. 1. Map of Thailand indicating the introduced apple snail (Pomacea canaliculata) and native apple snail (P. ampullacea, $P$. polita, P. pesmei and $P$. angelica) sample collection sites. Dots represent geographic locations from which at least one apple snail species was collected.

Five microliters of the amplified products were size-fractionated through $1.0 \%$ agarose gels to determine whether the expected fragment had been successfully amplified. Approximately $200 \mathrm{ng}$ of the amplified COI was separately digested with Dde I, Taq I, and $S s p$ I. The digests were electrophoretically analyzed using $2.0 \%$ agarose gels and visualized under a UV transilluminator after ethidium bromide staining (Maniatis et al., 1982).

Cloning and sequencing of 16S rDNA The 16S rDNA gene segments of native apple snails $(N=1$ for each species) and of Pomacea canaliculata (PcKKNE4 and PcSNNE1) were amplified by PCR using the $16 \mathrm{~S}$ primers; $16 \mathrm{~S}_{\mathrm{F}} ; 5^{\prime}$-CGC CTG TTT AAC AAA AAC AT-3', and $16 \mathrm{~S}_{\mathrm{R}}, 5^{\prime}$-CCG GTC TGA ACT CAG ATC ATG T-3' (Palumbi et al., 1991). The 560 bp product was gel-eluted and ligated to $\mathrm{pGEM}^{\mathrm{R}}-\mathrm{T}$ Easy vector (Hoelzel and Green, 1992). One-tenth of the volume of each ligation reaction was then electrotransformed into E. coli JM 109 (Dower et al., 1988). Recombinant clones were selected using a lac $Z$ system by following a standard protocol (Maniatis et al., 1982). The insert 
Table 1. Sampling collection sites and sample sizes of apple snails used in this study

\begin{tabular}{|c|c|c|c|}
\hline Species & Localities & Abbreviation* & Sample size $(N)$ \\
\hline \multirow[t]{14}{*}{ Pomacea canaliculata } & Chiangmai & PcCMN & 15 \\
\hline & $\mathrm{Phrae}^{\mathrm{a}}$ & PcPRN & 11 \\
\hline & Khonkhen $^{\mathrm{b}}$ & PcKKNE & 13 \\
\hline & Sakhonnakhon $^{\mathrm{c}}$ & PcSNNE & 13 \\
\hline & Taling Chun ${ }^{\mathrm{d}}$ & PcTCBK & 5 \\
\hline & Kasetsart University & PcKUBK & 12 \\
\hline & Nakhonnayok $^{\mathrm{e}}$ & PcNNC & 9 \\
\hline & Nakhonpathom $^{\mathrm{f}}$ & PcNPC & 12 \\
\hline & Suphanburi & $\mathrm{PcSPC}$ & 20 \\
\hline & Pathumthani & PcPTC & 18 \\
\hline & Ayutthaya ${ }^{g}$ & PcAYC & 18 \\
\hline & Uthaithani & PcUTC & 9 \\
\hline & Songkhla $^{\mathrm{h}}$ & PcSKPT & 13 \\
\hline & Phangnga $^{\mathrm{I}}$ & PcPNPT & 12 \\
\hline \multirow[t]{4}{*}{ P. ampullacea } & Don Maung & PaDMBK & 5 \\
\hline & Taling Chun $^{\mathrm{d}}$ & PaTCBK & 9 \\
\hline & Nakhonnayok $^{\mathrm{e}}$ & PaNNC & 11 \\
\hline & Nakhonpathom $^{\mathrm{f}}$ & PaNPC & 3 \\
\hline \multirow[t]{3}{*}{ P. polita } & Sakhonnakhon $^{\mathrm{c}}$ & PoSNNE & 12 \\
\hline & Phrae $^{a}$ & PoPRN & 10 \\
\hline & Phangnga $^{\mathrm{I}}$ & PoPNPT & 4 \\
\hline \multirow[t]{6}{*}{ P. pesmei } & Khonkhen $^{\mathrm{b}}$ & PeKKNE & 12 \\
\hline & Sakhonnakhon $^{\mathrm{c}}$ & PeSNNE & 10 \\
\hline & Roiet & PeRENE & 11 \\
\hline & Kalasin & PeKSNE & 9 \\
\hline & Nakhonpathom ${ }^{\mathrm{f}}$ & PeNPC & 10 \\
\hline & Ayutthaya ${ }^{g}$ & PeAYC & 11 \\
\hline \multirow[t]{3}{*}{ P. angelica } & Songkhla ${ }^{\mathrm{h}}$ & PanSKPT & 10 \\
\hline & Nakhonsithammarat & PanNSPT & 6 \\
\hline & Phangnga $^{\mathrm{I}}$ & PanPNPT & 11 \\
\hline
\end{tabular}

*Species names (Pc, Pa, Po, Pe or Pan) are followed by two capital letters to illustrate names of localities and one or two capital letters to reveal the regions (N, NE, C or PT).

Abbreviations: Pc , Pomacea canaliculata; Pa, P. ampullacea; Po, P. polita; Pe, P. pesmei; Pan, P. angelica; N, north; NE, northeast; C, Central region; PT, peninsular Thailand. Identical superscripts indicate that more than one species are co-occurred in that locality.

sizes were verified by colony PCR (Srisuparbh et al., 2003). Each insert was sequenced in both directions using an automated DNA sequencer (LI-COR, Lincoln, USA).

Primer design, species-specificity, and sensitivity tests The nucleotide sequences of $16 \mathrm{~S}$ rDNA were aligned using Clustal W (Thompson et al., 1994), and species-specific primers for Pomacea canaliculata were designed using OLIGO 4.0 (National Biosciences Inc.). A specificity test was carried out against the genomic DNA of Pomacea canaliculata $(N=131)$ and of nontarget species $(N=32,6,30$, and 14 for $P$. ampullacea, $P$. angelica, $P$. pesmei, and $P$. polita, respectively).

PCR was performed in a $25 \mu \mathrm{l}$ reaction volume using the reaction components described above. Thermal cycling involved predenaturation at $94^{\circ} \mathrm{C}$ for $3 \mathrm{~min}$ followed by 35 cycles of denaturation at $94^{\circ} \mathrm{C}$ for $1 \mathrm{~min}$, annealing at $53^{\circ} \mathrm{C}$ for $1 \mathrm{~min}$, and extension at $72^{\circ} \mathrm{C}$ for $1 \mathrm{~min}$. Final extension was performed at $72^{\circ} \mathrm{C}$ for $7 \mathrm{~min}$. The amplified product was analyzed electrophoretically in $1.6 \%$ agarose gels. The sensitivity of detection was determined using varying concentrations of Pomacea canaliculata genomic DNA (12.5 pg to $25 \mathrm{ng}$ ) using the conditions used for the species specificity test. The amplifications of total DNA (50 pg and $25 \mathrm{ng}$ DNA template) isolated from a fertilized egg and from juveniles of Pomacea canaliculata 1, 7, or 15 days old were also examined.

Data analysis Restriction profiles of COI were alphabetically coded in order of appearance. Each apple snail was assigned a three letter code (that of COI digested with Dde I, Taq I and Ssp I, respectively) to describe the composite haplotypes. The genetic distance between mtDNA composite haplotype $\left(d_{\mathrm{mtDNA}}\right)$, haplotype diversity $(h)$, and nucleotide diversity within samples $(\pi)$, and nucleotide divergence between samples $\left(d_{\mathrm{A}}\right)$ were calculated (Nei and Li, 1979; Nei and Tajima, 1981; Nei, 1987) using REAP (McElroy et al., 1991). A neighbor-joining tree (Saitou and Nei, 
1987) based on the percent sequence divergence between pairs of composite haplotypes was constructed using Neighbor in PHYLIP (Felsenstein, 1993). Geographic heterogeneities of allele distribution frequencies were analyzed (Guo and Thompson, 1992). $F_{\text {ST }}$ values between pairs of samples within species were tested to determine whether they differed significantly from zero (Weir and Cockerham, 1984) using Arlequin (Schneider et al., 1997). The significance levels of multiple test results were adjusted following the sequential Bonferroni method (Rice, 1989).

\section{Results}

PCR-RFLP The COIs of the introduced (Pomacea canaliculata) and of the native apple snails ( $P$. ampullacea, $P$ polita, $P$. pesmei and $P$. angelica) were subjected to restriction analysis using Dde I, Taq I, and Ssp I and generated 11, 7, and 2 digestion profiles, respectively (Fig. 2 and Table 2). Taq Idigested COI provided a species-specific RFLP profile (D) for $P$. ampullacea. Moreover, Pomacea canaliculata, $P$. ampullacea, and $P$. angelica were unambiguously discriminated by digesting COI with Dde I (Table 2).

In total, 21 composite haplotypes were found. No composite haplotypes were shared among species. Six composite haplotypes (DAA, AAB, DAB, AFB, DFA, and IAA) were observed in Pomacea canaliculata whereas three (EDA, KDA, and JDA), one (BAA), seven (BBA, BCA, CBA,

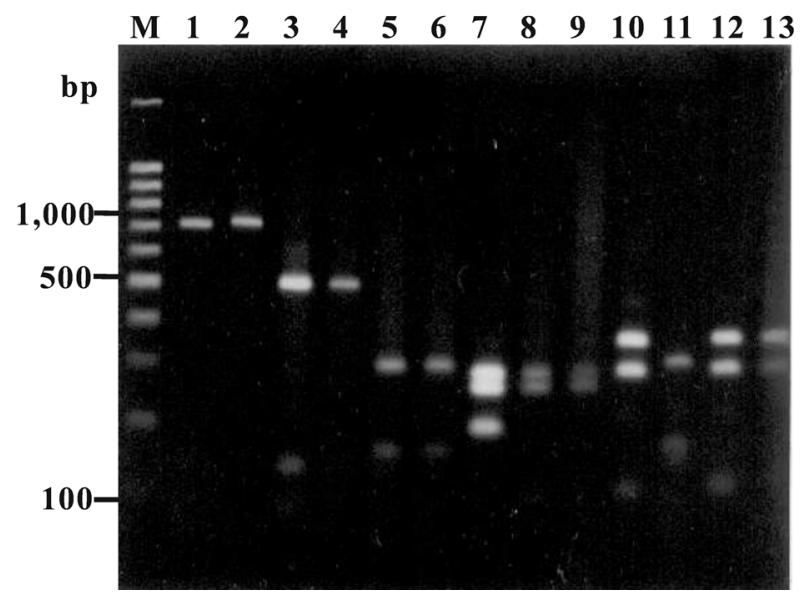

Fig. 2. Example of RFLP analysis of the amplified Dde Idigested COI of the apple snails with restriction pattern A (lanes 10, 12, 13), B (lanes 3-4), D (lanes 8-9), E (lanes 5-6), I (lane 7) and $\mathrm{K}$ (lane 11). Lanes 1 and 2 are of undigested COI gene segment. An 100 bp ladder (lane M) was used as a marker.

CCA, HCA, CGA, and CEA) and four (GBA, GCA, FBA, and FCA) were observed in $P$. ampullacea, $P$ polita, $P$. pesmei and $P$. angelica, respectively (Table 3 ). The genetic distance between pairs of composite haplotypes ranged between 0.41 $13.84 \%$.

Haplotype diversity and nucleotide diversity within samples

Table 2. Restriction fragment patterns resulted from digestion of COI of Pomacea canaliculata, P. ampullacea, P. polita, P. pesmei and $P$. angelica with restriction endonucleases

\begin{tabular}{|c|c|c|c|c|c|c|}
\hline \multirow{2}{*}{ Enzyme } & \multirow{2}{*}{ Pattern observed (bp) } & \multicolumn{5}{|c|}{ Species } \\
\hline & & $\mathrm{Pc}$ & $\mathrm{Pa}$ & Po & $\mathrm{Pe}$ & Pan \\
\hline \multirow[t]{11}{*}{ Dde I } & A: $350,275,100$ & + & - & - & - & - \\
\hline & B: $500,140,90$ & - & - & + & + & - \\
\hline & C: $400,140,90$ & - & - & - & + & - \\
\hline & D: $275,260,100$ & + & - & - & - & - \\
\hline & E: $300,160,140,90$ & - & + & - & - & - \\
\hline & F: 410, 250, 90 & - & - & - & - & + \\
\hline & G: 680 & - & - & - & - & + \\
\hline & H: 410, 140, 90 & - & - & - & + & - \\
\hline & I: $275,260,200$ & + & - & - & - & - \\
\hline & $\mathrm{J}: 325,200,100$ & - & + & - & - & - \\
\hline & $\mathrm{K}: 325,160,140$ & - & + & - & - & - \\
\hline \multirow[t]{7}{*}{ Taq I } & A: 640,120 & + & - & + & - & - \\
\hline & B: 550,120 & - & - & - & + & + \\
\hline & C: $550,120,110$ & - & - & - & + & + \\
\hline & D: $350,225,130$ & - & + & - & - & - \\
\hline & E: $425,130,120$ & - & - & - & + & - \\
\hline & F: 640,100 & + & - & - & - & - \\
\hline & G: $310,280,120$ & - & - & - & + & - \\
\hline \multirow[t]{2}{*}{$S s p$ I } & A: 710 & + & + & + & + & + \\
\hline & B: 490,220 & + & - & - & - & - \\
\hline
\end{tabular}

+ , found in investigated species. 
Table 3. Distribution frequencies of composite haplotypes of the introduced golden apple snail (Pomacea canaliculata) and native apple snails (P. ampullacea, P. polita, P. pesmei and P. angelica) based on restriction analysis of COI with Dde I, Taq I, and Ssp I

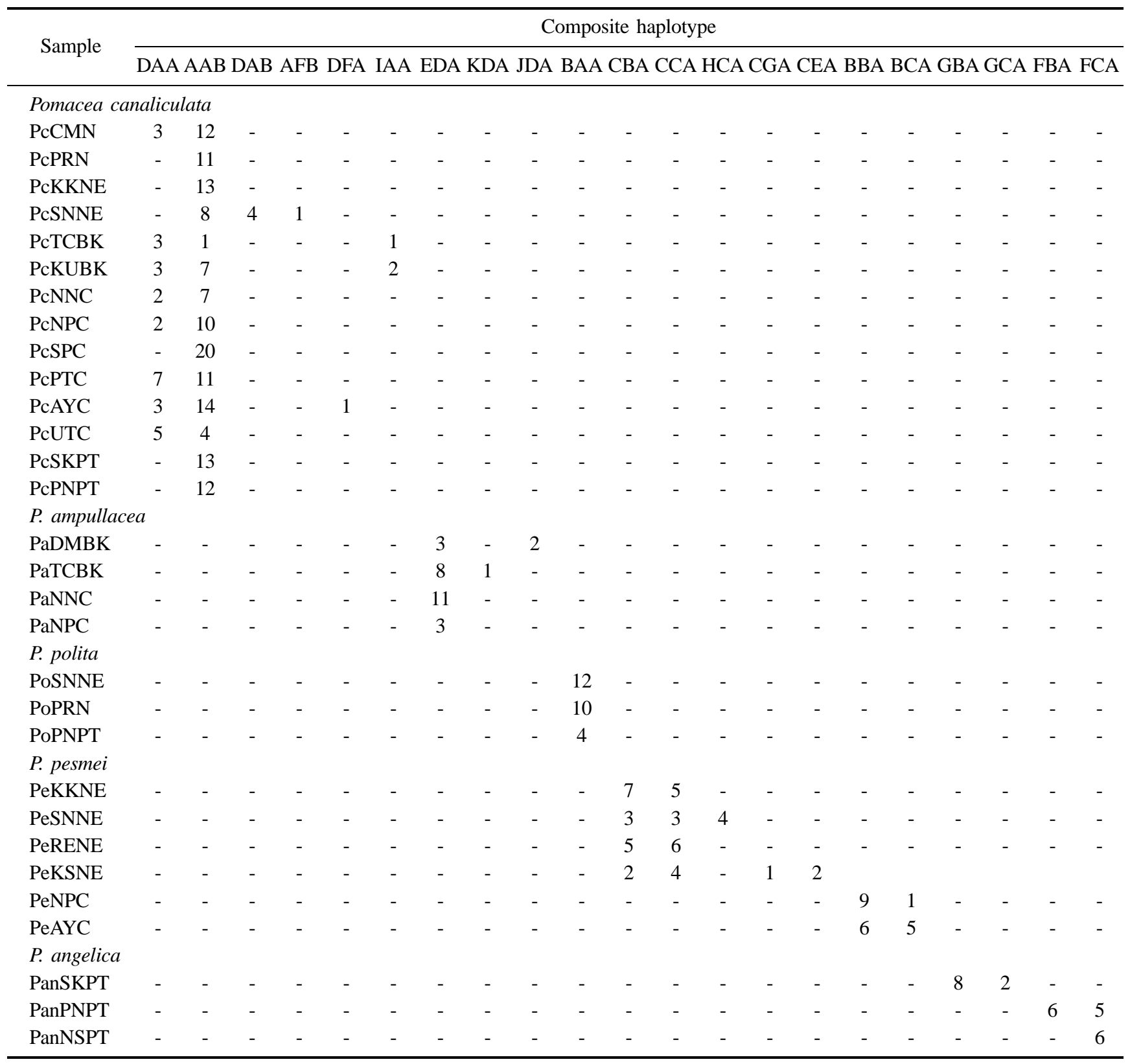

of Pomacea canaliculata varied between $0.00-0.70$ and 0.00 $1.96 \%$ with overall diversities of 0.35 and $0.98 \%$, respectively. Within Pila snails, $P$. polita and P. ampullacea exhibited lower genetic diversities than P. pesmei and P. angelica (Table 4). A large RFLP divergence was found between Pomacea canaliculata and Pila species (5.06-12.47\%). The lowest nucleotide divergence among these species was $1.61 \%(P$. angelica and P. pesmei).

A neighbor-joining tree constructed on the basis of genetic distance among pairs of composite haplotypes (Fig. 3), revealed clear species differentiation. Geographic heterogeneity analysis indicated significant differences between the composite haplotype distributions of the species $(\mathrm{P}<0.0001)$. Of the Pomacea canaliculata samples, 91 (the exact test) and 84 ( $F_{\text {ST }}$ statistics) of 91 possible comparisons were not significantly different after applying the sequential Bonferroni procedure $(\mathrm{P}>0.0036)$. Within Pila, the $P$. ampullacea $(\mathrm{P}=0.0881-1.000$ and $\mathrm{P}=0.0824-1.000$ for the exact test and the $F_{\mathrm{ST}}$ estimate, respectively) and the $P$. polita ( $\mathrm{P}=1.0000$ for both analyses) gene pools were panmictic. In contrast, population differentiation was observed between $P$. pesmei originating from the northeast and central regions ( $\mathrm{P}<0.0001$ for both analyses). Likewise, geographic population differentiation of $P$. angelica was observed 
Table 4. Haplotype and nucleotide diversity within samples of Pomacea canaliculata, $P$. ampullacea, $P$. pesmei, $P$. polita and $P$. angelica determined by restriction analysis of COI

\begin{tabular}{|c|c|c|}
\hline Sample & $\begin{array}{l}\text { Haplotype diversity } \\
\qquad(h \pm \mathrm{SE})\end{array}$ & $\begin{array}{l}\text { Nucleotide diversity } \\
\qquad(\times 100)\end{array}$ \\
\hline \multicolumn{3}{|c|}{ Pomacea canaliculata } \\
\hline PcCMN & $0.34 \pm 0.13$ & 1.04 \\
\hline PcPRN & $0.00 \pm 0.00$ & 0.00 \\
\hline PcKKNE & $0.00 \pm 0.00$ & 0.00 \\
\hline PcSNNE & $0.56 \pm 0.11$ & 0.55 \\
\hline PcTCBK & $0.70 \pm 0.22$ & 1.64 \\
\hline PcKUBK & $0.62 \pm 0.12$ & 1.96 \\
\hline PcNNC & $0.39 \pm 0.16$ & 1.18 \\
\hline PcNPC & $0.30 \pm 0.15$ & 0.92 \\
\hline PcSPC & $0.00 \pm 0.00$ & 0.00 \\
\hline PcPTC & $0.50 \pm 0.06$ & 1.53 \\
\hline PcAYC & $0.39 \pm 0.13$ & 1.24 \\
\hline PcUTC & $0.56 \pm 0.09$ & 1.69 \\
\hline PcSKPT & $0.00 \pm 0.00$ & 0.00 \\
\hline PcPNPT & $0.00 \pm 0.00$ & 0.00 \\
\hline Overall & $0.35 \pm 0.04$ & 0.98 \\
\hline \multicolumn{3}{|c|}{ P. ampullacea } \\
\hline PaDMBK & $0.60 \pm 0.18$ & 2.35 \\
\hline PaTCBK & $0.22 \pm 0.17$ & 0.30 \\
\hline PaNNC & $0.00 \pm 0.00$ & 0.00 \\
\hline PaNPC & $0.00 \pm 0.00$ & 0.00 \\
\hline Overall & $0.20 \pm 0.10$ & 0.62 \\
\hline \multicolumn{3}{|l|}{ P. polita } \\
\hline PoSNNE & $0.00 \pm 0.00$ & 0.00 \\
\hline PoPRN & $0.00 \pm 0.00$ & 0.00 \\
\hline PoPNPT & $0.00 \pm 0.00$ & 0.00 \\
\hline Overall & $0.00 \pm 0.00$ & 0.00 \\
\hline \multicolumn{3}{|l|}{ P. pesmei } \\
\hline PeKKNE & $0.53 \pm 0.08$ & 0.22 \\
\hline PeSNNE & $0.73 \pm 0.08$ & 0.69 \\
\hline PeRENE & $0.51 \pm 0.08$ & 0.21 \\
\hline PeKSNE & $0.78 \pm 0.11$ & 1.29 \\
\hline PeAYC & $0.55 \pm 0.07$ & 0.23 \\
\hline PeNPC & $0.20 \pm 0.15$ & 0.08 \\
\hline Overall & $0.79 \pm 0.02$ & 0.90 \\
\hline \multicolumn{3}{|l|}{ P. angelica } \\
\hline PanSKPT & $0.36 \pm 0.16$ & 0.16 \\
\hline PanNSPT & $0.55 \pm 0.07$ & 0.23 \\
\hline PanPNPT & $0.00 \pm 0.00$ & 0.00 \\
\hline Overall & $0.68 \pm 0.08$ & 1.50 \\
\hline
\end{tabular}

between PanSKPT-PanNSPT ( $\mathrm{P}=0.0004$ for both analyses) and PanSKPT-PanPNPT ( $\mathrm{P}<0.0001$ for both analyses) but not between PanNSPT-PanPNPT $(\mathrm{P}=0.0375$ and $\mathrm{P}=0.0053)$.

Species-specific PCR The length of the amplified 16S rDNA of the native apple snails (564-569 bp) was larger than that of Pomacea canaliculata (546 bp and $549 \mathrm{bp}$ ).

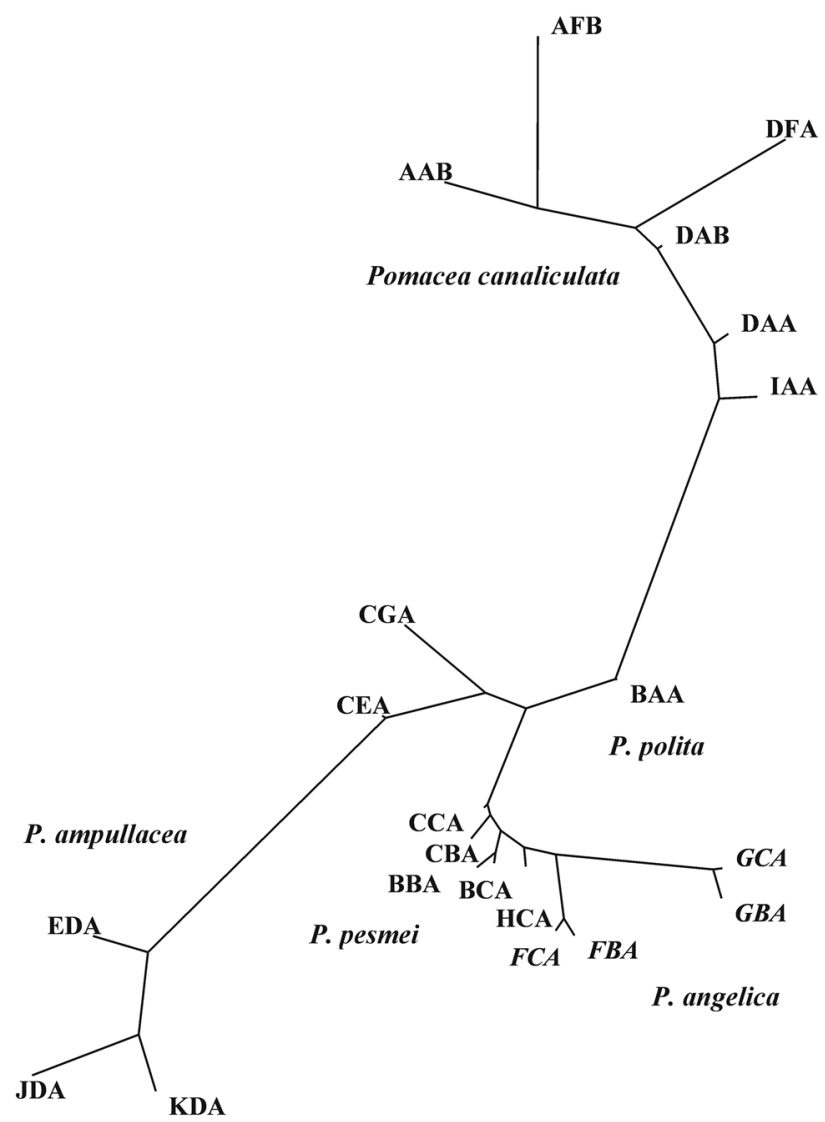

0.01

Fig. 3. A neighbor-joining tree summarizing the genetic relationships of Pomacea canaliculata, P. ampullacea, P. polita, $P$. pesmei, and $P$. angelica; constructed using the average genetic distance between pairs of composite haplotypes.

Divergence between the $16 \mathrm{~S}$ rDNA sequences of Pomacea canaliculata and Pila species was 16.88-19.60\% (calculated from the aligned sequences in Fig. 4). Within Pila, lower sequence divergences were found $(6.53-11.54 \%)$. A speciesspecific PCR product (KUPC1, $211 \mathrm{bp}$ ) was successfully identified for $P$. canaliculata (Fig. 5). The sensitivity of detection was approximately $50 \mathrm{pg}$ of the target genomic DNA template. Amplification of genomic DNA (50 pg and 25 $\mathrm{ng}$ ) isolated from fertilized eggs and juveniles (1, 7 and $15 \mathrm{~d}$ old) was also consistently successful.

\section{Dicussion}

RFLP analysis and species-diagnostic composite haplotypes in apple snails Based on a single enzyme digestion, Dde Idigested COI could differentiate Pomacea canaliculata (patterns A, D and I) from native Pila species accurately. In addition, the non-overlapped composite haplotypes of the apple snails allows simple and reliable species identification. 


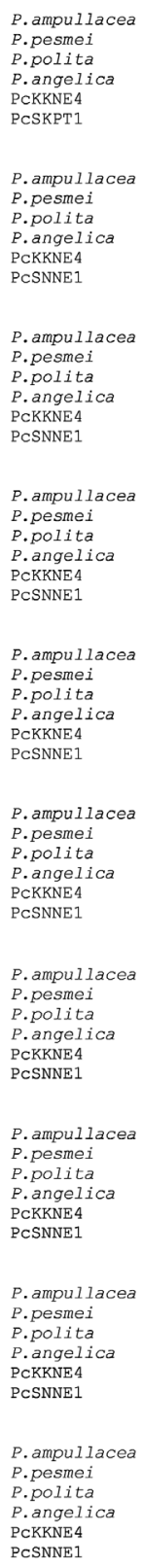

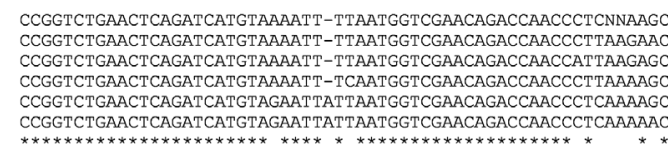

TTCTACACCCTTAGGA-TATTTTAATCCAACATCGAGGTCACAAACCTTT-CTTTCGATT TTCTACACCCTTAGGA-TATTTTAATCCAACATCGAGGTCACAAACCTTT-CTTTCGAT TTCTACACCCTTGGGAATATT T TAATCCAACATCGAGGTCACAAACCTTTTTCTTTCGAT TCACACCTTAGGA-TATTT TAATCCAACATCGAGGTCACAAACCTTT-CTTTCGAT

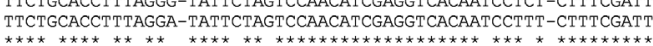

AGAACTCTTAAGATAGATTATGCTGTTATCCCTATGGTAACTTATTCTATTAATCAAAAT AGAACTCTTAAGATAGATTATGCTGTTATCCCTATGGTAACT TATTCTATTAATCAAAA AGAACTCT TAAGATAGATTATGCTGTTATCCCTATGGTAACT TATTCTAT TAATCAAAA AGACC

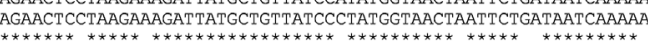
KUPC1F

ATTTTGGATC-AATTTAAATAAATCAATAT TAAATACTACAAAAACTCTGGAAGTTTTA ATT TTGGATC-AGT T TAAATAAGCTAATATTAAATATTATAAAA-CTCTGGAAGTTTCA ATTTTGGATCCAATTCAAATAAATTAATACTAAATATTATAAAA--TCTGGAAGT TTTG ATTTTGGATCAAATT TAAATAAATTAATAACAAATAATTCGGTA--TATGGAAGTT TTAC ATTTTGGATAAAAAACATA-AAATTAATT

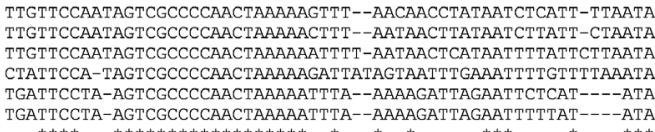
GATTCCTA-AGTCGCCCCAACTAAAAATTTA--AAAAGATTAGAATTTTTAT----ATA

TAATTTATGTTGTTATAAATCT TTAAAGCTCAATAGGGTCTTCTTGTCTAATAGTGAAAT CATCGTATGCTATTATAGATCTTTAAAGCTCAATAGGGTCTTCT TGTCTATTAGTAAAAT TAATTCATGTCATTATAAATCTCTTAAGCTCAATAGGGTCTTCTTGTCTATTAGTAACAT TAATTTATATTGCTATAGATTT TTAAAGCTCAATAGGGTCTTCTTGTCTATTAGTAATA TACCTTACTCCATAATAT-TTT TATAAGCTCAATAGGGTCTTCTTGTCTCTTAGTCATA TACTTTACTCTATAATAT-TTTTATAAGCTCAATAGGGTCTTCTTGTCTTTTAGTTATA

TTAAGCCTTTACACTTAAAAGTCAATTTCATTTTAATTTATATAAGAGACAGGCT AATTCTC TTAAGCCTTTACACTTAAAAGTCAATTTCATTTTAATTTATAAGAGACAGGCTAATTCTC TTAAGCCTTTGCACTTAAAAGTCAATTTCATTTTAGTTAGTAAGAGACAAACTAATTCTC TCAGGCCTTTGCACCTGAAGATCAATT TCATTTT TAATTTTGTAAAAGACAGGCT AATTCTT ATAAGCCTTTGCACTTATAAGTTAATTTCATCTTATACAAAAAAAAGACAGCCTAACTTTC

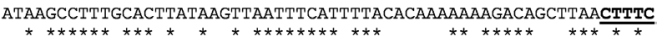

$* * * * * * * * * * * * * * * * * * * * * * \quad * * * * * * * * * * *$
kUPC1R
GTCAAACCATTCATACAAGCCTTTAATTATAAGGCAAATGATTATGCTACCTTTGCACGG GTCAAACCATTCATACAAGCCTTCAATTATAAGGCAAATGATTATGCTACCTTTGCACGG

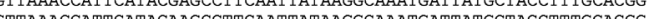
GTTAAACCTCTCATACTAGCCTTCAATTATAAGGCAAATGATT'ATGCTACCTTCCACGG

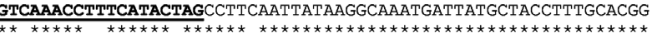

TCAGAGTACCGCGGCCGTTAAA-TCTTTATCACTGGGCAGGTCAGGCTCTTTATGTA--T TCAGAGTACCGCGGCCGTTAAAATATATATATCACTGGGCAGGTTAGACTCTTTATAAAA-T TCAGAGTACCGCGGCCGTTAAA-TAAACATCACCGGGCAGGTTAGACTCTTTATAAAAAT TCAAAGTACCGCGGCCGTTAAA---AAAATCACTGGGCAGGTTAGACTCTTTATATTAAC TCA

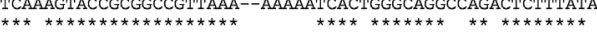

CAGTANNAAGAGACATGTTTTTGTTAAACAGGCG AAAAACAAAGAGACATGTTTTTGTTAAACAGGCG GTAAACAAAGAGACATGTTTTTGTTAAACAGGCG ATAAACAAAGAGCCATGITTTTGITAAACAGGCG ATAAGCAAAGAGCCATGTTTTTGTTAAACAGGCG

Fig. 4. Sequences of $16 \mathrm{~S}$ rDNA of $P$. ampullacea, $P$. pesmei, $P$. polita, P. angelica, and Pomacea canaliculata (PcKKNE4 and PcSNNE1). The locations and sequences of Pomacea canalicalata-specific forward primer (KUPC1F), and those complementary to a reverse primer (KUPC1R) appear in boldface and underlined.

Brandt (1974) and Keawjam (1986) reported that $P$. polita is abundantly distributed in the north, northeast, and central regions of Thailand, but it is not found on the Thai peninsula. However, we found apple snails with the external characteristics of $P$. polita in a number of locations on the peninsula. Specimens from Phangnga $(N=4)$ were included in the analysis, and these possessed a BAA composite haplotype, which is found only in $P$. polita. This is the first

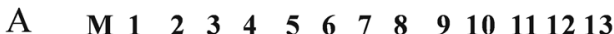

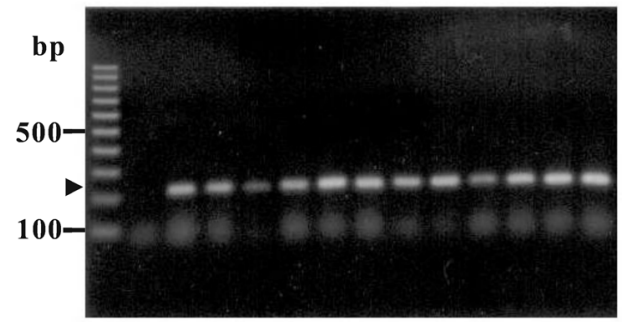

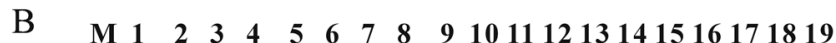

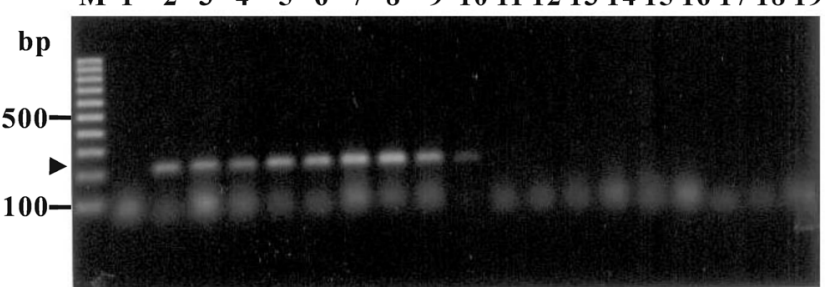

Fig. 5. Agarose gel electrophoresis showing the specificity of KUPC1F/R primers to the genomic DNA of Pomacea canaliculata (panels A lanes 2-13 and B lanes 2-10), $P$. ampullacea (B, lanes 11-12), P. pesmei (B, lanes 13-15), $P$. polita (B, lanes 16-17) and P. angelica (B, lanes 18-19). Lane 1 contains negative controls (without Pomacea canaliculata DNA). Arrowheads indicate a $211 \mathrm{bp}$ PCR product. A 100 bp ladder (lanes M) was used as the DNA marker.

report of $P$. polita on the Thai peninsula.

Only one or two common composite haplotypes were found in most populations of the apple snails. Nonoverlapping distribution patterns of COI composite haplotypes of apple snails suggested a lack of hybridization at both the intergeneric and interspecific levels. Practically, copulation between male Pomacea canaliculata and female P. pesmei under laboratory conditions is possible but the females did not subsequently lay eggs (C. Janyapeth, personal communication). Nevertheless, the possibility of hybridization and gene introgression between these taxa cannot be ignored unless the nuclear genetic markers of these snails are scrutinized.

Although only a limited number of native apple snails were analyzed, specimens were collected from most parts of the species ranges and should have been representative. We did not include Pila gracilis in the present study, because it was not found, although this apple snail has been reported in provinces below Phangnga (Keawjam, 1986).

Genetic diversity and the differentiation of apple snails It has been reported that the cytochrome $\mathrm{b}$ (cyt $b$ ) gene accumulates nucleotide changes at a rate that is sufficient to resolve phylogenetic relationships among closely related species (Collins et al., 1996). However, when Tinti et al., (2002) analyzed the genetic stock structure of the sardine (Sardina pilchardus) originating from the Adriatic (10 geographic sample, $N=285$ ) and Ionian Seas (1 geographic sample, $N=22$ ) by sequencing a 307-bp cyt $b$ gene segment, they found a lack of intraspecific genetic subdivision among 
Table 5. Geographic heterogeneity analysis and $F_{\mathrm{ST}}$ estimate between pairs of geographic samples of native apple snails ( $P$. ampullacea, P. polita, $P$. pesmei, and $P$. angelica) in Thailand

\begin{tabular}{|c|c|c|}
\hline Species & Geographic heterogeneity analysis & $F_{\mathrm{ST}}$ estimate \\
\hline \multicolumn{3}{|l|}{ P. ampullacea } \\
\hline PaDMBK-PaTCBK & $\mathrm{P}=0.1197^{\mathrm{ns}}$ & $\mathrm{P}=0.1120^{\mathrm{ns}}$ \\
\hline PaDMBK-PaNNC & $\mathrm{P}=0.0881^{\mathrm{ns}}$ & $\mathrm{P}=0.0824^{\mathrm{ns}}$ \\
\hline PaDMBK-PaNPC & $\mathrm{P}=0.4704^{\mathrm{ns}}$ & $\mathrm{P}=0.4575^{\mathrm{ns}}$ \\
\hline PaTCBK-PaNNC & $\mathrm{P}=0.4475^{\mathrm{ns}}$ & $\mathrm{P}=0.4560^{\mathrm{ns}}$ \\
\hline PaTCBK-PaNPC & $\mathrm{P}=1.0000^{\mathrm{ns}}$ & $\mathrm{P}=1.0000^{\mathrm{ns}}$ \\
\hline PaNNC-PaNPC & $\mathrm{P}=1.0000^{\mathrm{ns}}$ & $\mathrm{P}=1.0000^{\mathrm{ns}}$ \\
\hline \multicolumn{3}{|l|}{ P. polita } \\
\hline PoSNNE-PoPRN & $\mathrm{P}=1.0000^{\mathrm{ns}}$ & $\mathrm{P}=1.0000^{\mathrm{ns}}$ \\
\hline PoSNNE-PoPNPT & $\mathrm{P}=1.0000^{\mathrm{ns}}$ & $\mathrm{P}=1.0000^{\mathrm{ns}}$ \\
\hline PoPRN-PoPNPT & $\mathrm{P}=1.0000^{\mathrm{ns}}$ & $\mathrm{P}=1.0000^{\mathrm{ns}}$ \\
\hline \multicolumn{3}{|l|}{ P. pesmei } \\
\hline PeKKNE-PeSNNE & $\mathrm{P}=0.0861^{\mathrm{ns}}$ & $P=0.1394^{\text {ns }}$ \\
\hline PeKKNE-PeRENE & $\mathrm{P}=0.6890^{\mathrm{ns}}$ & $\mathrm{P}=0.6806^{\mathrm{ns}}$ \\
\hline PeKKNE-PeKSNE & $\mathrm{P}=0.1264^{\mathrm{ns}}$ & $\mathrm{P}=0.2746^{\mathrm{ns}}$ \\
\hline PeKKNE-PeNPC & $\mathrm{P}<0.0001 *$ & $\mathrm{P}<0.0001 *$ \\
\hline PeKKNE-PeAYC & $\mathrm{P}<0.0001^{*}$ & $\mathrm{P}<0.0001^{*}$ \\
\hline PeSNNE-PeRENE & $\mathrm{P}=0.0830^{\mathrm{ns}}$ & $\mathrm{P}=0.1402^{\mathrm{ns}}$ \\
\hline PeSNNE-PeKSNE & $\mathrm{P}=0.1135^{\mathrm{ns}}$ & $\mathrm{P}=0.1886^{\mathrm{ns}}$ \\
\hline PeSNNE-PeNPC & $\mathrm{P}<0.0001 *$ & $\mathrm{P}<0.0001^{*}$ \\
\hline PeSNNE-PeAYC & $\mathrm{P}<0.0001 *$ & $\mathrm{P}<0.0001 *$ \\
\hline PeRENE-PeKSNE & $\mathrm{P}=0.2547^{\mathrm{ns}}$ & $\mathrm{P}=0.4122^{\mathrm{ns}}$ \\
\hline PeRENE-PeNPC & $\mathrm{P}<0.0001 *$ & $\mathrm{P}<0.0001 *$ \\
\hline PeRENE-PeAYC & $\mathrm{P}<0.0001 *$ & $\mathrm{P}<0.0001 *$ \\
\hline PeKSNE-PeNPC & $\mathrm{P}<0.0001 *$ & $\mathrm{P}<0.0001^{*}$ \\
\hline PeKSNE-PeAYC & $\mathrm{P}<0.0001^{*}$ & $\mathrm{P}<0.0001 *$ \\
\hline PeNPC-PeAYC & $\mathrm{P}=0.1451^{\mathrm{ns}}$ & $\mathrm{P}=0.0641^{\mathrm{ns}}$ \\
\hline \multicolumn{3}{|l|}{ P. angelica } \\
\hline PanSKPT-PanNSPT & $\mathrm{P}<0.0004^{*}$ & $\mathrm{P}<0.0004 *$ \\
\hline PanSKPT-PanPNPT & $\mathrm{P}<0.0001^{*}$ & $\mathrm{P}<0.0001 *$ \\
\hline PanNSPT-PanPNPT & $\mathrm{P}=0.0375^{\mathrm{ns}}$ & $\mathrm{P}<0.0053^{*}$ \\
\hline
\end{tabular}

Significance levels were adjusted following the sequential Bonferroni procedure (Rice, 1989).

geographic samples. Conversely, we found both inter- and intraspecific genetic heterogeneity among indigenous oysters in Thailand based on the COI polymorphism (Klinbunga et al., 2003). This gene segment was also successfully used to identify genetic differentiation and biased female gene flow in the giant tiger shrimp, Penaeus monodon (Klinbunga et al., 2001). Therefore, we selected COI rather than cyt $b$ for population genetic studies of apple snails in Thailand.

Haplotype and nucleotide diversity within species was relatively low in Pomacea canaliculata and $P$. ampullacea, and no COI polymorphism was found in $P$. polita. Higher genetic diversity was found in $P$. pesmei and $P$. angelica.

The estimation of haplotype and nucleotide diversity in the present study is based solely on haplotype frequencies and the band sharing of RFLP patterns (Graves and McDowell, 1994). Although the digestion of COI with 3 restriction enzymes was sufficient for species identification, more restriction enzymes would be needed to provide more accurate estimates of genetic diversity in these taxa.

Pomacea canaliculata was introduced to Thailand only about two decades ago (Keawjam and Upatham, 1990). The conventional rate of evolution for mitochondrial genes is about $1 \times 10^{-8}$ substitutions per site per year per evolutionary line (Brown et al., 1979). Therefore, the diversity of COI shown by this species is probably the result of multiple introductions to Thailand from different geographic origins rather than by COI substitutions through evolutionary time. In addition, the sequence divergence shown by the 16S rDNA gene segment among representative Pomacea canaliculata individuals (PcKKNE4 and PcSNNE1) was 3.74\%, further suggesting a time lapse of approximately 3.74 million years since the last common ancestor.

Intraspecific genetic substructuring was observed in $P$. pesmei and $P$. angelica. The former is commonly distributed 
in central and northeast Thailand but is rare in the north and absent from the Thai peninsula (Keawjam, 1986). RFLP analysis of $\mathrm{COI}$ indicates fragmentation of the $P$. pesmei gene pool into the northeast (PeKKNE, PeSNNE, PeRENE and PeKSNE) and the central (PeAYC and PeNPC) groups ( $\mathrm{P}<$ 0.0001). Likewise, differentiation within $P$. angelica (PeSKPT -PeNSPT, $\mathrm{P}<0.0001$ and PeSKPT-PePNPT, $\mathrm{P}=0.0004$ ) was also observed.

Both Pomacea canaliculata and Pila snails are natural hosts of Angiostrongylus cantonensis (Chen, 1935), which causes eosinophilic meningoencephalitis in humans (Witoonpanich et al., 1991; Keawjam et al., 1993). Pipitgool et al. (1997) surveyed Angiostrongylus infection in snails collected from northeast Thailand and found $0.0 \%$ and $0.9 \%$ infection prevalences in $P$. polita $(N=77)$ and $P$. ampullacea $(N=423)$, respectively. Using RFLP markers, the species-origins of apple snails can be identified unambiguously, therefore, the parasite prevalence can be investigated in more detail (i.e., the determination of host species, the evaluation of the susceptibilities of species to parasites, and the determination of relationships between the distributions of the different snail species and the prevalences of $A$. cantonensis). Moreover, the existence of population differentiation in $P$. pesmei and $P$. angelica allow the prevalence of infection in different snail populations to be evaluated.

Molecular taxonomy of apple snails Pomacea apple snails in Thailand have been identified as Pomacea canaliculata, Pomacea insularum, and Pomacea sp. (Keawjam and Upathum 1990). Although Pomacea apple snails were genetically examined using 9 monomorphic and 4 polymorphic (Est-3, Hbdh-1, Idh and Pgm-2) loci, qualitative data (band patterns) rather than quantitative data (allele frequencies, genetic distances, geographic heterogeneities, and $F$ statistics) were reported. Therefore, the results were premature with respect to evaluating the species diversity of Pomacea in Thailand. Our results indicate that the gene pool of Pomacea snails in Thailand is panmictic ( $\mathrm{P}>0.0036)$. Accordingly, it should be recognized as a single species rather than 3 different species.

Annadale (1920) recognized seven species and two races of Pila snails in Thailand, whereas Brandt (1974) classified these snails into 5 species; P. ampullacea, $P$. gracilis, $P$. pesmei, $P$. polita, and $P$. scutata, and placed $P$. angelica under $P$. pesmei. Subsequently, Keawjam (1986) viewed $P$. scutata as a rare non-banded form of $P$. gracilis, but differentiated $P$. angelica from $P$. pesmei. Only $P$. polita can be easily distinguished morphologically, whereas $P$. gracilis can be misidentified as a small form of $P$. pesmei, and $P$. angelica as a large form of $P$. pesmei. In addition, small $P$. angelica is similar to young $P$. ampullacea.

Our results indicate that $P$. pesmei and $P$. angelica should not be regarded as a single species. The phylogenetically close relationship between $P$. angelica and $P$. pesmei supports the taxonomic difficulties reported by earlier morphological and geographic distribution studies. The ability to distinguish native apple snails using diagnostic composite haplotypes of COI resolves taxonomic problems in the genus Pila in Thailand.

Pomacea canaliculata-specific PCR based on the 16S rDNA polymorphism A rapid and simple method for differentiating Pomacea canaliculata and Pila apple snails during the early stages of development is required. Moreover, a marker specific to Pomacea canaliculata could allow the detection of its gene introgression, if any, into the gene pools of native Pila snails. The ability to identify the species-origin of Pomacea canaliculata, without any false positives using as little as 50 pg of genomic DNA extracted from fertilized eggs, juveniles, or adults of Pomacea canaliculata demonstrates the high specificity and sensitivity of the KUPC1 marker. Distinguishing between Pomacea canaliculata and Pila apple snails by species-specific PCR is more cost-effective and convenient than typical PCR-RFLP analysis, and can be used to discriminate these species at the early stages of development.

Acknowledgments We thank the National Center for Genetic Engineering and Biotechnology (BIOTEC), the National Science and Technology Development Agency (NSTDA), the Department of Zoology and the Department of General Science, Faculty of Science, Kasetsart University for providing facilities. We also thank Piti Ampayup for technical assistance.

\section{References}

Annadale, N. (1920) The apple snails of Siam. J. Nat. Hist. Soc. Siam 40, 1-24.

Brandt, R. A. M. (1974) The non-marine aquatic mollusca of Thailand. Archiv. fur. Molluskenkunde 105, 1-423.

Brown, W. M., George, M., Jr. and Wilson, A. C. (1979) Rapid evolution of animal mitochondrial DNA. Proc. Natl. Acad. Sci. USA 76, 1967-1971.

Collins, T. M., Frazer, K., Palmer, A. R., Vermeij, G. J. and Brown, W. M. (1996) Evolutionary history of northern hemisphere Nucella (Gastropoda, Muricidae): molecular, morphological, ecological and paleontological evidence. Evolution 50, 2287-2304

Cowie, R. H. (2002) Apple snails as agricultural pests: their biology impact and management; in Mollusca as Crop Pests, Barker, G. M. (ed.), pp. 145-192. CAB international, Wallingford, UK.

Dower, W. J., Miller, J. F. and Ragsdale, C. W. (1988) High efficiency transformation of $E$. coli by high voltage electroporation. Nucleic Acids Res. 16, 6127-6145.

Felsenstein, J. (1993) Phylip (Phylogenetic inference Package) version 3.5c. Distributed by the author. Department of Genetics, University of Washington, Seattle, USA.

Folmer, O., Black, M., Hoeh, W., Lutz, R. and Vrijenhoek, R. (1994) DNA primers for amplification of mitochondrial 
cytochrome c oxidase subunit I from diverse metazoan invertebrates. Mol. Mar. Biol. Biotechnol. 3, 294-299.

Graves, J. E. and McDowell, J. R. (1994) Genetic analysis of striped marlin (Tetrapturus audax ) population structure in the Pacific Ocean. Canadian J. Fish. Aquat. Sci. 51, 1762-1768.

Guo, S. W. and Thompson, E. A. (1992) Performing the exact test of Hardy-Weinberg proportion of multiple alleles. Biometrics 48, 361-372.

Hoelzel, A. R. and Green, A. (1992) Analysis of population-level variation by sequencing PCR-amplified DNA; in: Molecular Genetic Analysis of Populations, Hoelzel, A. R. (ed.), pp. 159187. Oxford University Press, Oxford, UK.

Janyapeth, S. and Archawakom, T. (1999) Biology of the alien apple snails. in The Alien Apple Snail, Thai Ministry of Agriculture and Cooperatives, pp. 1.1-1.15. Pailin Hotel, Phitsanulok, Thailand.

Keawjam, R. S. (1986) The apple snails of Thailand: distribution habitat and shell morphology. Malacol. Rev. 19, 61-81.

Keawjam, R. S. (1987) The apple snails of Thailand: aspects of comparative anatomy. Malacol. Rev., 20, 69-89.

Keawjam, R. S. and Upatham, E. S. (1990) Shell morphology, reproductive anatomy and genetic patterns of three species of apple snails of the genus Pomacea in Thailand. J. Med. Appl. Malacol. 2, 45-57.

Keawjam, R. S., Poonswad, P., Upatham, E. S. and Banpavichit, S. (1993) Natural paracitic infection of the golden apple snail, Pomacea canaliculata. Southeast Asian J. Trop. Med. Pub. Health 24, 170-177.

Klinbunga, S., Khamnamtong, N., Tassanakajon, A., Puanglarp, N., Jarayabhand, P. and Yoosukh, W. (2003) Molecular genetic tools for three commercially cultured oysters (Crassostrea belcheri, Crassostrea iredalei and Saccostrea cucullata) in Thailand. Mar. Biotechnol. 5, 27-36.

Klinbunga, S. Siludjai, D., Wuthijinda, W., Tassanakajon, A., Jarayabhand, A. and Menasveta, P. (2001) Genetic heterogeneity of the giant tiger shrimp (Penaeus monodon) in Thailand revealed by RAPD and mtDNA-RFLP analyses. Mar. Biotechnol. 3, 428-438.

Lauhachinda, N., Duangswasdi, S. and Sidhi, S. (1988) South America golden apple snails (Pomacea canaliculata) the new pest of aquatic plants. Kasetsart University Conference Report 26, 108-115.

Maniatis, T., Sambrook, J. and Fritsch, E. F. (1982) Molecular Cloning: A Laboratory Manual. Cold Spring Harbor Press, Cold Spring Harbor Laboratory, New York, USA.

McElroy, D., Moran, P., Birmingham, E. and Kornfield, I. (1991) REAP (Restriction Enzyme Analysis Package) version 4.0 University of Maine, Orono, Maine, USA.
Nei, M. (1987) Molecular Evolutionary Genetics Columbia University Press, New York, USA.

Nei, M. and Li, W. H. (1979) Mathematical model for studying genetic variation in terms of restriction endonucleases. Proc. Natl. Acad. Sci. USA 76, 5269-5273.

Nei, M. and Tajima, F. (1981) DNA polymorphism detectable by restriction endonucleases. Genetics 97, 145-163.

Palumbi, S. R., Martin, A., Romano, S., McMillan, W. O., Stice, L. and Grabowski, G. (1991) The Simple Fools Guide to PCR, Version 2. Zoology Department, University of Hawaii, USA.

Pipitgool, V., Sithithaworn, P., Pongmuttasaya, P. and Hinz, E. (1997) Angiostrongylus infections in rats and snails in northeast Thailand. Southeast Asian J. Trop. Med. Pub. Heal. 28 (suppl 1), 190-193.

Rice, W. R., (1989) Analyzing tables of statistical tests. Evolution 41, 223-225.

Saitou, N. and Nei, M. (1987) The neighbor-joining method: a new method for reconstructing phylogenetic trees. Mol. Biol. Evol. 4, 406-425.

Schneider, S., Kueffer, J. M., Roessli, D. and Excoffier, L. (1997) Arlequin 1.1: a software for population genetic data analysis Genetics and Biometry Laboratory, University of Geneva, Geneva, Switzerland.

Srisuparbh, D., Klinbunga, S., Wongsiri, S. and Sittipraneed, S. (2003) Isolation and characterization of major royal jelly cDNAs and proteins of the honey bee (Apis cerana). J. Biochem. Mol. Biol. 36, 572-579.

Thompson, J. D., Higgins, D. G. and Gibson, T. J. (1994) Clustal W: improving the sensitivity of progressive multiple sequence weighting, position-specific gap penalties and weight metric choices. Nucleic Acids Res. 22, 4673-4680.

Tinti, F., Di Nunno, C., Guarniero, I., Talenti, M., Tommasini, S., Fabbri, E. and Piccinetti, C. (2002) Mitochondrial DNA sequence variation suggests the lack of genetic heterogeneity in the Adriatic and Ionian stocks of Sardina pilchardus. Mar. Biotechnol. 4, 163-172.

Weir, B. S. and Cockerham, C. C. (1984) Estimating F-statistics for the analysis of population structure. Evolution 38, 13581370.

Winnepenninckx, B., Backeljau, T. and De Wachter, R. (1993) Extraction of high molecular weight DNA from molluscs. Trends Genet. 9, 407.

Witoonpanich, R., Chuahirum, S., Soranastaporn, S. and Rojanasunan, P. (1991) Eosinophilic myelomeningoencephalitis caused by Angiostrongylus cantonensis: a report of three cases. Southeast Asian J. Trop. Med. Pub. Heal. 28 (suppl 1), 190193. 